\title{
NEFORMALNO IZOBRAŽEVANJE V KOSTANIEVICI NA KRKI
}

Natalija Goričar studentka Filozofske fakultete

\section{Neformalno izobraževanje spodbuja lokalni razvoj}

Tr ljudi, kje vidijo možnosti za svoje neformalno izobraževanje, večina ni vedela, kaj pravzaprav želimo od njih izvedeti. Se pravi, da se kot prvi problem pojavi vprašanje, ali se ljudje zavedajo, da se neformalno izobražujejo. Kako imenujejo to izobraževanje?

Neformalno izobraževanje je po Philipu Coombsu in sodelavcih »vsaka organizirana izobraževalna dejavnost zunaj vpeljanega formalnega sistema - pri tem ni pomembno, ali deluje samostojno ali kot pomemben del širše dejavnosti -, ki je namenjena izbranim učencem in zadovoljuje določene učne smotre« (Neformalno izobraževanje odraslih, Ljubljana, 1994, str. 56).

Iz te opredelitve je izpeljana opredelitev, ki govori o neformalnem izobraževanju odraslih in po kateri je neformalno izobraževanje (Kleis, 1974: 6) »vsaka intencionalna in sistematična izobraževalna dejavnost (navadno zunaj tradicionalnega šolanja), pri kateri gibljivo izbiramo vsebine, medije, časovne enote, vpisna merila, osebje, sredstva in druge sistemske sestavine ter jih prilagajamo izbranim udeležencem, populacijam in okoliščinam, da bi tako z zmanjšanjem sistemskih ovir čimbolj povečali uspešnost učenja v skladu s postavljenimi smotri.«

Tudi po Unescovi terminologiji je neformalno izobraževanje odraslih »izobraževanje odraslih, pri katerem je učenje sicer namerno, učni proces pa ni strukturiran $\mathrm{v}$ obliki razredov pod vodstvom učitelja, ki naj bi bil odgovoren za izobraževanje učencev, niti ni potrebno, da bi se proces organiziral sosledično«.

Iz teh opredelitev je očitno, da je neformalno izobraževanje nastalo kot alternativa šolskemu izobraževanju, kar navajajo številni avtorji celo kot razlog za njegov nastanek (Neformalno izobraževanje odraslih, Ljubljana, 1994, str. 56).

Sami smo ljudem razlagali, da gre za tematsko izobraževanje, zunaj profesionalnih ustanov, pri katerem se viri, čas in kraj nenehno spreminjajo. Učinkovitost je zelo velika, ker poteka spontano in je prilagojeno posamezniku - izhaja iz njegovih življenjskih razmer. Neformalno izobraževanje je pomembna možnost za srečevanje in združevanje ljudi. Pojavlja se kot stranski proizvod družbe, organizacij, socialnih skupin, prostega časa in družine.

Neformalno
izobraževanje-
alternativa šolske-
mu izobraževanju.

Pomen neformalnega izobraževanja lahko izrazimo $\mathrm{z}$ njegovimi specifičnimi možnostmi, ki se kažejo v povezanosti s krajevnimi viri, iz katerih črpa, ki se jim prilagajajo in so vpete v njihovo dogajanje. Grandstaff meni, da je to »podporno « izobraževanje, ki poteka ob določenih dejavnostih, bodisi občasno ali daljši čas, in se po vsebini prilagaja njihovim potrebam. 
Neformalno izobraževanje odraslih lahko še posebej pripomore $\mathrm{k}$ razvoju v lokalni ali območni skupnosti. Pripomore tudi $\mathrm{k}$ krepitvi zavesti, povečanju produktivnosti kmetijstva, večji udeleženosti prebivalstva pri odločanju, zboljšanju pokliene usposobljenosti manj izobraženih prebivalcev, uspešnem izvajanju dobro pripravljenih vladnih programov (Neformalno izobraževanje $v$ delovnih organizacijah, Ljubljana, 1992).

Eden izmed krajev z bogato zgodovinsko, kulturno, turistično in društveno tradicijo, kjer se skrivajo mnogoštevilne možnosti neformalnega izobraževanja, je tudi najstarejše dolenjsko mesto, Kostanjevica na Krki. Naš namen je predstaviti in osvetliti možnosti, ki se skrivajo za temi atributi. Ljudje so si tu sčasoma ustvarili življenje, ki se še posebej izraža v kulturni tradiciji. Živijo od vrednot, in to je tisto, kar je v njih. To pa bi bilo nemogoče brez animacije prebivalcev, ki se začne že v šolskih klopeh in družini.

Francoski mislec Paul Lengrand je zapisal: »Kultura je vse tisto, kar ostane, ko smo vse drugo pozabili. Je vse tisto, kar nas spremeni. To ni znanje. Sčasoma se podrobnosti izgubijo, ostanejo le koščki vedenja, ostane preostanek in na tistem, kar preostane, gradimo vse drugo. Ta preostanek je vir strasti, radovednosti, vedoželjnosti. Kultura se kaže tudi v razmišljanju, ki nas navdaja. Lahko nas žene želja po spoznanju, to so lahko občutki sreče in čustev, ki jih delimo z drugimi ljudmi. Če je tako, ta preostanek, ta sled, ta kultura, ki se $\mathrm{z}$ nami stara in ki se pomladi z našimi otroki, ostane najlepše darilo tega sveta«. Ta misel diha in živi v srcih tukajšnjih ljudi od rojstva do smrti.

\section{KOSTANJEVICA NA KRKI, NAJSTAREJŠE DOLENJSKO MESTO}

Približno na pol poti med Novim mestom in Brežicami stoji najstarejše dolenjsko mesto, leta 1091 , kot trg leta 1249 in kot mesto leta
1252. Leta 2002 bo Kostanjevica praznovala 750-letnico mestnih pravic. Staro mestno jedro današnjega mesta je nastalo na umetnem otoku v meandru reke Krke, na ravnici v podnožju Gorjancev ob jugovzhodnem robu Krške kotline. Otok ima obliko slikarske palete. Kostanjevica je primer živega mesta na otoku, ki mu ni podobnega niti v Sloveniji niti drugje. Zaradi pogostih poplav se je Kostanjevice prijelo ime dolenjske Benetke. Zadnjih 170 let ni bila deležna posebnega razvoja. Tako kot mnogi dolenjski kraji je bila tudi Kostanjevica poseljena že v pradavnini. $\mathrm{Ob}$ obzidju samostana so našli sledove pračloveka, nedaleč stran pa je arheolog dr. Srečko Brodar odkril prazgodovinski čoln. Na samem otoku so odkrili predmete iz keltskih in rimskih časov: zapestnico, dele nagrobnikov, pokrov sarkofaga, kamen $\mathrm{z}$ reliefom trte in mnoge druge dragocene predmete. Ker Kostanjevica nima muzeja, so ti predmeti shranjeni v Narodnem muzeju v Ljubljani in druje po svetu (na primer v Fogovem muzeju na harvardski univerzi). Kako se je naselje imenovalo v času Keltov in Ilirov, ni znano. Ime naselbine Landestros (deželna tolažba), ki je nastalo ob nekdanjem istoimenskem kostanjeviškem gradu kot spanheimski obmejni trdnjavi, je bilo prvič zapisano leta 1091, ko so bili lastniki naselbine koroški vojvode Spanheimi. Kasneje se je naselbina preimenovala $v$ Landstrasse (deželna cesta). V Valvasorjevi Slavi vojvodine Kranjske sta omenjeni dve slovenski imeni: Kostainaveza in Kostainovza. Mestne pravice je Kostanjevica dobila leta 1252. Imela je tudi kovnico denarja (od 1210 do 1275). Po izumrtju Spanheimov so mestu gospodarili češki kralj Otokar, goriški grofje, gospodje Svibenjski in celjski grofje. Leta 1439 je prišlo do bitke med Habsburžani in Celjani, ki so obdržali mesto. Po izumrtju Celjanov je Kostanjevica pripadala Habsburžanom. Leta 1469 je turška vojska prvič napadla Kostanjevico in nato še štirikrat. Mesto so pogosto ropali uskoki, kar nam 
prikazuje tudi freska na samostanskem vhodu. Vsi ti pretresi sedemnajstega stoletja so nekdaj cvetočo Kostanjevico vztrajno pehali v propad. Malokdo ve, da je Josip Ressel v 19. stoletju preizkušal delovanje ladijskega vijaka v okolici Kostanjevice. V obdobju pred prvo svetovno vojno in do druge svetovne vojne je bila Kostanjevica močno upravno središče s sodiščem, zemljiško knjigo, davčno in cestno upravo, odvetniško pisarno ter gozdno upravo. Daleč naokoli je bila znana tudi lekarna svetega Miklavža, ki jo je opremil priznani arhitekt Jože Plečnik. Po drugi svetovni vojni, ko so odpravili občino, je mesto ponovno nazadovalo.

Mesto Kostanjevica ima sedemsto prebivalcev, celotna krajevna skupnost pa šteje dvatisoč sedemsto prebivalcev. To mestece razpolaga $s$ kar petimi razstavišči in devetimi različnimi društvi, v katerih se ljudje družijo med seboj in se tako ali drugače učijo vrednot, odgovornosti, strpnosti, odnosov, življenja in, kot bomo videli v nadaljevanju, še marsičesa.

\section{LOKALNA SREDIŠČA NEFORMALNEGA IZOBRAŽEVANIA}

\section{Razstavišča}

\section{Galerija Božidar Jakac}

Začetki galerijske dejavnosti segajo $\mathrm{v}$ leto 1956, ko so na pobudo Lada Smrekarja, tedanjega ravnatelja osnovne šole, $v$ njenih prostorih ustanovili Gorjupovo galerijo. V njej so razstavljena podarjena dela domačih in tujih avtorjev 20. stoletja.

Leta 1958 se ji je pridružil še Lamutov likovni salon, v katerem so občasne razstave priznanih slovenskih in tujih avtorjev.

Galerija Božidar Jakac je bila ustanovljena leta 1974 v obnovljenih dvoranah nekdanjega cistercijanskega samostana. Ime nosi po slovenskem slikarju in grafiku Božidarju Jakcu, ki je galeriji podaril obsežno zbirko svojih del in jo tudi podprl (Razvedrilo, poletje 98, str. 43, 1998).

Galerija hrani približno 4.000 umetnin. Tu domujejo stalne slikarske, kiparske in grafične zbirke, predvsem dela slovenskih ekspresionistov: Toneta Kralja, Franceta Kralja, Božidarja Jakca, Jožeta Gorjupa, zbirka kipov Franceta Goršeta, kipi iz brona in slike Janeza Boljke ter slike Zorana Didka. Na ogled je tudi zbirka starih mojstrov, sposojena iz bližnje kartuzije Pleterje.

Če bi ugotavljali obisk glede na državljanstvo, je tu največ prav Slovencev, sledijo jim Hrvati, Italijani, Avstrijci, Nemci, Nizozemci, Belgijci, Francozi, Poljaki, Rusi, Španci, Američani, Brazilci, Kitajci. Z galerijo se seznanjajo že predšolski in šolski otroci ter dijaki, ki tu preživljajo zadnje dni osnovne in srednje šole. Obiskujejo jo tudi študentje, upokojenci, mlajše družine, skratka ljudje v vseh življenjskih obdobjih. Sem prihajajo ljudje zelo različnih poklicev in statusov: politiki, delavci, upokojenci, kmetje, poslovni partnerji slovenskih podjetij - tuji in domači. Po izobrazbi so to ljudje $\mathrm{z}$ osnovno, poklicno, srednjo, višjo in visoko šolo, magisterijem ali doktoratom.

V galeriji se lahko obiskovalci seznanijo z zgodovino Kostanjevice, samostana, osnovne šole, si ogleda zbirko slovenskih ekspresionistov in njen umetniški fond ter fond osnovne šole. Pri tem spoznajo motive, značilne za ekspresionizem, ter grafične in slikarske tehnike, naučijo se razumevati sodobno slikarstvo, kiparstvo, grafiko.

Krajani pridejo predvsem na otvoritve razstav, koncerte in poroke, ki potekajo v samostanski cerkvi. Razstave si načrtno ogledajo šolarji, sicer pa domačini le redko pridejo, mnogi celo ne vedo, da imajo prost vstop.

Obiskovalce zanima zgodovina samostana, razvoj ekspresionizma na naših tleh - odkod vplivi, katere zbirke so na ogled, kje se dajo kupiti dela, življenje umetnikov, cistercijanov, kdo financira obnovo samostanskega kom- 


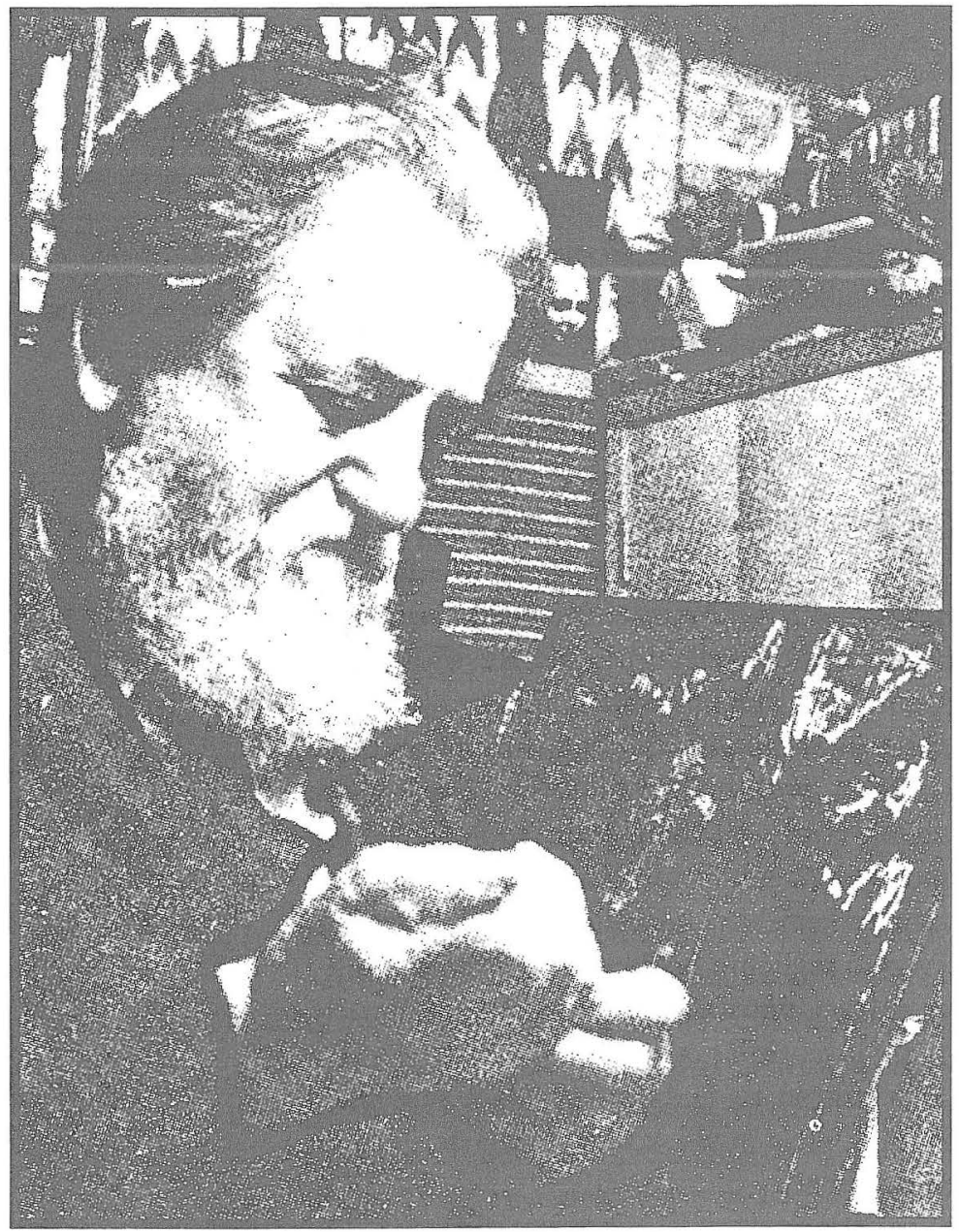

pleksa, od kod in čemu tako bogata umetniška zakladnica $v$ tako majhnem kraju, kot je Kostanjevica.

Ljudje pridejo sem, da bi si ogledali galerijo zbirke, razstave, skulpture Forma vive, arhitekturo samostana in cerkve (študentje umetnostne zgodovine, arhitekture, gradbeništva ...), da bi uživali lepo okolico, pridejo kot izletniki, ki jim je Kostanjevica ena od izletniških točk.

V samostanu potekajo tudi otvoritve razstav. Nanje pridejo tisti, ki dobijo vabila - ljudje iz sveta umetnosti, kulture (slikarji, kiparji, grafiki, kustusi, vodje galerij ...), glasbeniki, prijatelji umetnika - razstavljalca in Kostanjevičani oziroma prebivalci krajevne skupnosti
Kostanjevica. V povprečju se njihova starost giblje od 40. do 60. leta. Gre pa za intelektualce, umetnike, direktorje in preproste ljudi. V samostanu je tudi knjižnica Toneta Potokarja, katere fond znaša približno 5.000 podarjenih knjig. Knjižnica je interne narave le za potrebe Galerije Božidar Jakac, kajti ta nima zaposlenega, ki bi bil odgovoren za knjižnico. V njej je leposlovna, strokovna, poljudno-znanstvena literatura, potekajo pa tudi sestanki, seje, tečaji (na primer tečaj nemškega jezika) za potrebe galerije. Tu so še številne neizrabljene možnosti, ki bi jih galerija lahko ponudila svojim krajanom: uredila bi lahko čitalnico in tudi organizirala najrazličnejše strokovne seminarje. Veliko krajanov za to knjižnico sploh še ni slišalo.

Veliko je domačinov, ki ne vedo, da imajo prost vstop. Ali pa ne vedo natančno, kaj je v galeriji razstavljeno, kaj vse si lahko ogledajo, v katero likovno smer spadajo razstavljena dela, kdo so umetniki, ki imajo stalne razstave, kakšno bogastvo umetnin pomeni pravzaprav ta galerija in kako bogato zgodovino hranijo zidovi nekdanjega samostana.

Kmečki prebivalci bolj redko zaidejo v galerijo, čeprav vedo zanjo, saj so bili kot otroci večkrat $\mathrm{v}$ njej, vendar dobro poznajo predvsem polpreteklo zgodovino in kakšne so bile zgradbe med drugo svetovno vojno in po njej - kako je potekala obnova.

Tudi zaposlene smo povprašali, v čem vidijo prednosti njihovega dela. Govorili so o tem, da spoznajo umetnike in se seznanijo z njihovimi deli ter slogom. Predvsem nepoklicni vodniki, brez umetnostnozgodovinske izobrazbe, se naučijo veliko o zgodovini samostana, pravilih, načinu življenja menihov - cistercijanov. Pri svojem delu se srečujejo $\mathrm{z}$ umetniki in njihovimi prijatelji, ki večkrat povedo, kaj zanimivega iz njihovega življenja. Želijo pa si predvsem kulturno omikane obiskovalce, ki se znajo vesti $v$ galerijah in muzejih, izboljšati delovne razmere (pozimi je $\mathrm{v}$ galeriji zelo mrzlo) in 
menijo, da bi bilo treba ponudbo galerije združiti z gostinsko ponudbo.

Marginalizirane skupine, kot so invalidi, imajo prost vstop in brezplačno vodstvo ne glede na to, ali pridejo kot posamezniki ali kot skupina.

\section{Forma viva}

Likovno podobo Kostanjevice na Krki dopolnjujejo lesene skulpture, nastale $\mathrm{v}$ letih 1961-1988 v okviru mednarodnega simpozija kiparjev Forma viva, ki je sestavni del Galerije Božidar Jakac in tudi razpoznavno znamenje Kostanjevice na Krki. Tu gre za kipe iz hrastovega lesa in delo 133 umetnikov z vsega sveta. Te skulpture so v okolici galerije, na nekdanjih samostanskih vrtovih. V letu 1998 je po desetletnem premoru v organizaciji galerije ponovno oživel mednarodni kiparski simpozij Forma viva, kjer zbrani kiparji oblikujejo novo formo, mogočna debla oživljajo $\mathrm{z}$ novim sporočilom. Tu lahko zvemo vse, od vrst lesa, primernih za tovrstno obdelavo, do orodij, potrebnih zanjo.

\section{Osnovna šola}

Svojevrstna posebnost kraja je kostanjeviška osnovna šola $\mathrm{z}$ umetnostno zbirko - Gorjupovo galerijo, v kateri je razstavljenih 217 podarjenih del, skupno pa šteje zbirka že nad 2.000 enot domačih in tujih avtorjev. Gre za stalno postimpresionistično razstavo likovnih del. Razstavljena so na šolskih hodnikih in stenah. Na steni šole je $184 \mathrm{~m}^{2}$ velik monumentalni mozaik bitke na Krškem polju iz časov kmečkih uporov. To je največji mozaik v Sloveniji (Ivan Seljak Čopič, Tambosso Alfio Ultra, 1982).

Spominja nas na zgodovino $\mathrm{v}$ teh krajih in šolarji jo iz generacije $v$ generacijo spoznavajo in živijo $\mathrm{z}$ njo v zavesti po spoštovanju odločitev svojih prednikov. $S$ to dediščino vstopajo tudi v mladost in v zrelosti se še poglobi. Če v mladosti živiš s tako bogato kulturo, ki kliče tudi po razumu, da se bi ohranila, se to mora nekje pokazati. In to se bolj ali manj izraža prav v delovanju in čustvovanju domačinov. Otroci postajajo že v najnežnejših letih šolanja odgovorni in poklicani, da ohranijo to, kar jim je zaupano. Pri njih se začne vzbujati občutek, da so izbrani, da jih spremlja umetnost. To ti »zleze pod kožo«. Za to ni ne učbenikov, predpisov ne pravil. To je način življenja.

\section{Lamutov likovni salon}

V samem mestnem jedru stoji graščina, ki jo je po razpustitvi samostana leta 1793 mestna občina kupila za župnišče in jo delno preuredila v šolske prostore. Te so leta 1958 preuredili v Lamutov likovni salon. Pred vhodom je spomenik domačinu Ivanu Oražnu, prvemu starosti jugoslovanskega Sokola, ki je svoje premoženje namenil ustanovitvi in vzdrževanju medicinske fakultete ter študentskega doma (Oražnov študentski dom na Wolfovi ulici v Ljubljani). Tu prirejajo občasne razstave grafike, slik in otroških risb - Extempore.

\section{Društva}

V Kostanjevici je devet registriranih društev:

Turistično društvo se je zelo razvilo v zadnjih letih. V okviru društva je pomemben zlasti turistični podmladek, ki ga sestavljajo osnovnošolci. Udeležujejo se raznih tekmovanj in so zelo aktivni $\mathrm{v}$ medšolskih tekmovanjih $\mathrm{v}$ turizmu. Na tem področju dosegajo, posebej v zadnjem času, odlične rezultate in osvajajo prva mesta.

\section{Kulturno društvo je imelo}

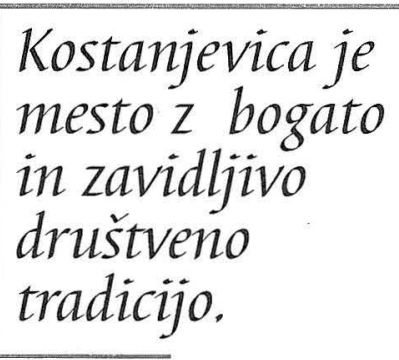
svoje čase zelo pomembno vlogo. Danes v okviru društva deluje plesna skupina Harlekin, ki je prav tako uspešna. Poleg tega društvo vsaj enkrat na leto organizira kulturno prireditev, ki je namenjena krajanom. 
Športno društvo je zelo dejavno. V sodelovanju s sosednjimi športnimi društvi vsako leto organizirajo kolesarski maraton $\mathrm{z}$ imenom Rudijev memorial s številnimi udeleženci. Znan je tek po dolenjskih Benetkah, kot včasih imenujemo Kostanjevico. Vsako leto organizirajo veslaško regato, $\mathrm{v}$ njihovih vrstah pa skrbijo še za nogometne, košarkarske in druge športne aktivnosti.

Jamarski klub je dejaven predvsem $\mathrm{v}$ zadnjih letih. Kot je znano so leta 1997 odkrili novo jamsko dvorano. Raziskovanje jame pa se še nadaljuje. Torej si lahko obetamo novo izobraževalno aktivnost.

Lovsko društvo skrbi za preživetje divjadi pozimi, predvsem pa za naravno ravnotežje

Društva, kot ena pomembnejših možnosti neformalnega izobraževanja, skrbijo tudi za svoj podmladek. živali v naravi. Med martinovanjem organizirajo lov na divjad. V društvu se lovci med seboj družijo, lov pa je zanje predvsem konjiček.

Ribiška družina se zavzema, da je $\mathrm{v}$ Krki in potokih dovolj rib ter za čiste vode, zato organizirajo tudi čistilne akcije.

Imajo svoj ribolovni bazen, kjer gojijo krape. Prirejajo tudi ribiška tekmovanja. Posebej so ponosni, da bodo leta 2000 organizatorji svetovnega ribiškega prvenstva. Na to se že aktivno pripravljajo.

Društvo vinogradnikov je eno najpomembnejših društev. Njegova naloga je propagiranje cvička, zavzema se za vinske ceste, organizira vsakoletne vinske razstave ter cvičkarije v Kostanjevici in tudi v Novem mestu, saj sodeluje s tamkajšnjimi vinogradniki. Prireja izlete po vinorodnih okoliših doma in v tujini. $\mathrm{Na}$ srečanjih razpravlja o vinogradniških opravilih in si izmenjuje informacije, izkušnje in znanje. Prireja tudi tečaje kletarjenja, ki so zelo obiskani.

Aktiv kmečkih žena prireja skoraj na vseh krajevnih prireditvah pogostitve $\mathrm{v}$ kmečkem duhu, sodeluje s petjem domačih ljudskih pe- smi ter pripravlja okusno domače pecivo. Imajo svojo nošo in se pri medsebojnem druženju zabavajo ter sprostijo.

Avtomoto društvo enkrat na leto organizira srečanje Pot v neznano. Druži jih veselje do avtomobilizma.

\section{Malo mestno gledališče}

Malo mestno gledališče je amaterska gledališka skupina $\mathrm{v}$ okviru lokalnega kulturnega društva. Ne gre za običajno gledališko skupino, kajti zanjo je značilno, da navadno deluje skozi vse leto in vsaj enkrat na leto uprizori predstavo. Malo mestno gledališče deluje bolj projektno, kar pomeni, da ko pride do določene zamisli, se ta uresniči v čimbolj doglednem času. Med posameznimi projekti pa lahko mine tudi mesece in več dolgo brezdelje. Ustvarja celovite predstave, kot je na primer njihova Ob-ljubiti, sodeluje pri drugih predstavah (na primer plesna skupina Harlekin, koncert mladinskega pevskega zbora Seraphicum) in tudi prireja samostojne nastope (recitacije). Poleg tega načrtuje tudi izvedbo kreativne delavnice, $v$ katerih želijo povezati čim več ustvarjalnih mladih. Ena izmed njihovih dejavnosti je tudi raziskovanje gledališke preteklosti v Kostanjevici.

Gledališče šteje devet članov, ki so študentje različnih fakultet. Aktivnih članov pa je toliko, kolikor jih sodeluje pri konkretnem projektu.

Struktura obiskovalcev, ki obiskujejo predstave, je različna od projekta do projekta, vedno pa zelo raznovrstna in bi jo težko opredelili glede na starost, status in druge družbene kategorije. Lahko rečemo, da je publika tega gledališča mikro vzorec makrične gledališke publike.

\section{Oblike javnega druženja v gostilnah}

Kot značilnost tako majhnega mesta, kot je Kostanjevica, lahko navedemo tudi številne 
gostilne. Če se sprehodite, jih lahko naštejete kar osem. Tri izmed njih se lahko upravičeno pohvalijo z najboljšimi jedmi in pijačami ter prenočišči na visoki ravni. To vam bodo potrdili prav gotovo vsi njihovi gostje, ki so bolj ali manj stalni. Gre za gostilne $\mathrm{z}$ bogato tradicijo, ki privabljajo zahtevnejše goste iz sveta podjetništva gospodarstva. Ko smo obiskali eno od njih, smo imeli priložnost to tudi opazovati. To so srečanja na visoki ravni, v podjetniškem duhu. $\mathrm{S}$ tem mislimo na komunikacijo, odnose med partnerji in navsezadnje na držo in uglajenost. Pogovori so odvisni predvsem od narave druženja. Če gre za sklepanje poslov, so s tem povezane tudi teme pogovorov. Gre pa predvsem za družabno povezovanje ljudi in tudi za ustvarjalno delo ter osebno uveljavljanje. Poleg tega pa za pretok znanja, informacij, nova spoznanja, nove priložnosti, skratka za vse, kar prinaša napredek.

Tu pa se ne srečujejo samo poslovneži, temveč tudi domačini. Na občasnih obiskih smo skoraj vedno naleteli na iste obraze. To nam je potrdil tudi natakar. Povedal nam je nekaj zanimivih opažanj. Najpogostejše teme pogovorov je aktualno dogajanje $\mathrm{v}$ politiki in gospodarstvu, vendar pa to postane kmalu dolgočasno in nadomesti ga opravljanje, ki ga $v$ tako majhnem mestu zlepa ne zmanjka. Lahko bi rekli, da tu »vsi vse vedo o vseh «. Natakar nam je skoraj z obžalovanjem povedal, da pri tem opravilu moški celo prekašajo ženske, ki se v gostilnah ne zbirajo v tolikšnem številu, kar pa nikakor ne pomeni, da jih ni ali da zanje to ne bi bilo zanimivo.

Ženske smo tu srečali najpogosteje v dopoldanskih urah, ko hodijo po nakupih za gospodinjstvo. To so predvsem ženske, ki imajo lastno obrt in jim le ta dopušča gibljivo delo, ženske »na čakanju«, mlade upokojenke. Na vprašanje, o čem se pogovarjajo, so nam odgovorile, da jih zanima, kar se dogaja novega, vsakdanji problemi, ki jih skušajo kdaj

rešiti tudi skupaj, saj vemo, da več glav več ve.

Šolsko mladino (zadnja leta osnovne šole in srednješolci) najdete $\mathrm{v}$ baru in piceriji, ki sta popoldne in sploh proti večeru, predvsem ob koncu tedna, polna. Mladina tu išče družbo in zavezništvo med vrstniki. Največkrat se dobijo, da bi se skupaj zabavali in kovali načrte, kako preživeti čas. Tu so si našli svoj kotiček ne le zaradi druženja in pijače, ampak tudi družabnih aktivnosti, kot so biljard, pikado in razne igrice na avtomatih. Združuje pa jih predvsem želja po prijateljstvu in potreba, da se vsaj občasno umaknejo od doma. V okrilju svojih vrstnikov iščejo »določeno socialno varnost in trdnost samospoštovanja ter zaslombo« (Ana Krajnc, Metode izobraževanja odraslih, str. 248, Ljubljana, 1979). Tu sprostijo odvečno energijo, za to pa imajo priložnost tudi v dokaj razgibani športni dejavnosti, ki se še posebej razmahne $\mathrm{v}$ poletnih mesecih. Poleti jim pomenijo zabavo kopanje v Krki in vožnja s čolni, različne igre z žogo (odbojka, košarka, nogomet), kolesarjenje,

Najpogostejše teme gostilniških pogovorov so aktualni dogodki iz lokalne skupnosti in tudi po svetu. sprehodi. Med šolskim letom pa se družijo pri zunajšolski dejavnosti, ki poteka v okviru šole, udeležuje se je tudi pošolska mladina. Srečevanje z mladimi zunaj lokalne skupnosti pa jim omogočajo številne diskoteke v širši okolici.

Tukajšnji študenti se povezujejo in družijo s študenti iz Novega mesta in Posavja. V svojem kraju pogrešajo mladinske prostore, kjer bi po svojih močeh pripomogli k razvoju kraja in se pri tem sami kaj naučili ter se zabavali. Sicer pa pogosto ostajajo kar v Ljubljani ali Mariboru, kjer študirajo in imajo na izbiro kulturne, športne in zabavne prireditve. Med njimi pa je veliko takih, ki ostajajo zvesti domačemu kraju in redno prihajajo domov. 


\section{MEDIJI IN ŠIRŠE MOŽNOSTI ZA NEFORMALNO IZOBRAŽEVANJE}

\section{Časopis}

$\mathrm{Na}$ območju Kostanjevice izhaja enkrat na mesec glasilo krajevne skupnosti Kostanjevica na Krki z naslovom Novice. Naklada je tisoč izvodov, glasilo pa ima tudi svoj uredniški odbor, ki šteje pet članov. Vsaka družina ga dobi vsak mesec brezplačno po pošti. $\mathrm{V}$ njem so obvestila sveta krajevne skupnosti (Svet KS obvešča), v katerem obveščajo krajane o delu sveta KS, predlogih in načrtih ter delih, ki jih načrtujejo. V sklopu obvestil so tudi razpisi za različna gradbena dela, pripravo in oddajo programov za vključitev v praznovanja, podelitev priznanj in drugo, pove-

\section{Lokalni časopis krajani redno prebirajo.}

zano $s$ to temo. Naslednji sklop, ki sestavlja glasilo, so Dogodki. Gre za predstavitev pomembnejših dogodkov, ki so se zgodili v preteklem mesecu. V eni od številk smo tako brali o srečanju sošolk in sošolcev, rojenih leta 1928 in 1929, ki so obiskovali Ljudsko šolo v Kostanjevici (ki deluje že od leta 1906), z zanimivim naslovom Kako večno teče Krka po dolini, tako večni na mladost so nam spomini ... Brali smo tudi o novih prostorih banke, črščenju dna Krke, popisu ptic v Krakovskem gozdu, ki spadajo v kostanjeviško območje in so uvrščene na seznam evropsko pomembnih lokalitet ptic (Important Bird Area). Iz članka smo izvedeli, da so v njem še posebej pomembni črna štorklja, orel, mali klinček, golobi duplarji in zavidljiva populacija srednjih detljev in belovratih muharjev. Glasilo ima na koncu tudi Šolsko stran, na kateri pišejo le učenci tukajšnje osnovne šole. Poročajo o popotovanjih in ekskurzijah, športnih in likovnih tekmovanjih, kulturni dejavnosti in dogajanju na šoli. Svojo stran imajo tudi društva in klubi (Društva in klubi), ki ravno tako poročajo o dogajanju v svojih vrstah. Tako smo brali o reševalni va- ji iz jame, o pohodu, ki ga je organiziralo Turistično društvo, in tradicionalnem poletnem promenadnem koncertu pihalnega orkestra, popestrenem s Trdinovimi pripovedkami o skrivnostnih Gorjancih. Zadnja stran pa je namenjena obvestilom o prireditvah in oglasom (Obvestila in oglasi). O tem smo brali v osmi, julijski številki. Ker glasilo ni obsežno, so nam vsi, ki smo jih povprašali, ali ga redno prebirajo, odgovorili pritrdilno. Domačini so to glasilo dobro sprejeli, saj jih sproti obvešča o dogajanju, o katerem zagotovo večina izmed njih ne bi veliko vedela.

Glede časopisja kot širšega medija so ljudje največ naročeni na dnevnika Dnevnik in Slovenske novice ter tednike Nedeljski dnevnik, Kmečki glas in Dolenjski list. Slednji je časopis dolenjske in posavske regije in ravno zato domač prebivalcem teh krajev, ki jim je tudi namenjen. Tu se zbirajo novice iz vseh dolenjskih občin (Novo mesto, Šentjernej, Metlika, Črnomelj, Semič, Suhor, Kočevje, Ribnica, Dobrepolje, Trebnje) in posavskih občin (Krško, Brežice, Sevnica). Vključuje teme iz gospodarstva, kmetijstva, kulture, poročila o nesrečah, športu, zanimivostih, reportaže, dopise, televizijski spored, obvestila in osmrtnice. Kdo je nanj naročen, bi težko posploševali, a vseeno smo ugotovili, da gre predvsem za prebivalce obrobnejših predelov. Ko smo povprašali manjšo skupino desetih ljudi, ki so naročeni nanj, kaj najpogosteje prebirajo, so nam odgovorili, da so to oglasi, osmrtnice in nesreče. Lahko rečemo, da je tako najverjetneje zaradi populacije, ki je nanj naročena, saj gre večinoma za manj izobražene ljudi. Ljudje pa radi prebirajo tudi tako imenovane črne strani. Dolenjski list slovi kot »rumeni« časopis, zlasti med bolj izobra ženimi sloji prebivalstva. Uslužbenka na pošti nam je povedala, na naše presenečenje, da je časopis Delo tu zelo redek in da so nanj naročeni le nekateri, predvsem ljudje z višjim socialnim statusom in višjo izobrazbo.

V trafiki smo vprašali prodajalko, kateri ča- 


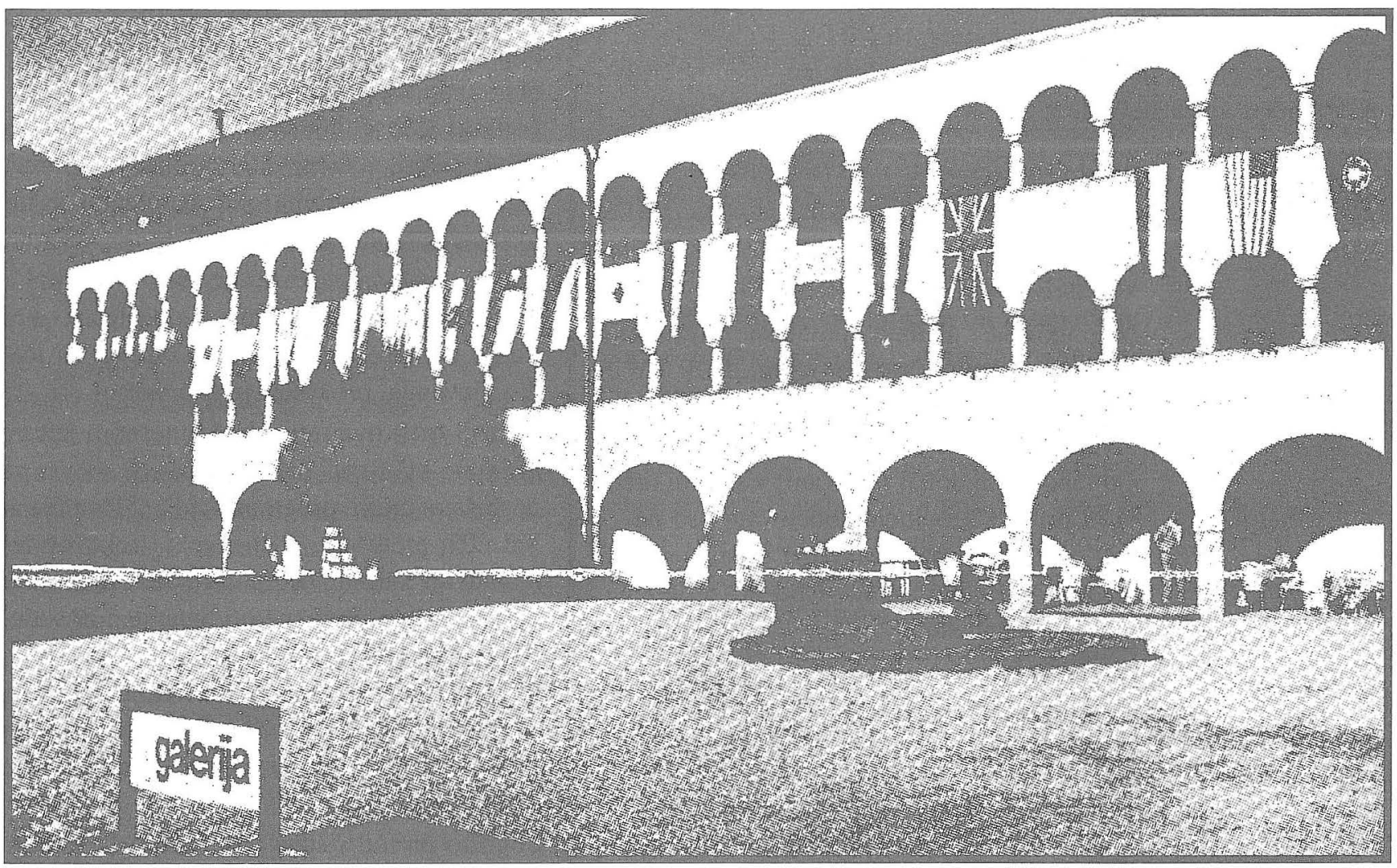

sopisi se najbolje prodajajo in za katere je največje zanimanje. Povedala nam je, da so to Lady, Jana, Naša žena, ki jih kupujejo predvsem ženske s povprečnim socialnim in družbenim statusom. Zanimanje pa je še za Družino ter časopise in revije, kot so Mag, Mladina in Delo. Gre za revije in časopise, za katere je pri tukajšnjih prebivalcih že manjše povpraševanje, saj zahtevajo širšo razgledanost.

\section{Televizija Novo mesto}

Je regionalni televizijski program, namenjen gledalcem Bele krajine, Dolenjske in Posavja. Imenuje se Vaš kanal. Z oddajnika, ki stoji na Trdinovem vrhu, na meji s Hrvaško, ga na kanalu 41 lahko spremlja nekaj sto tisoč prebivalcev na slovenskem ozemlju in še nekajkrat toliko na drugi strani.

Program se začne vsak dan ob štirinajsti uri, ob nedeljah ob trinajsti uri in traja do desete ure zvečer. Začne se $\mathrm{z}$ videostranmi, ki vsebujejo obvestila o razstavah, muzejih, menjalniškem tečaju, društvih, proslavah, kino predstavah, dežurnih trgovinah, cenah različnih proizvodov, ponudbi kmetijskih strojev in mehanizacije. Na njihovih straneh pa si lahko gledalci ogledajo tudi Kmetijske razglede, ki so zelo dobro sprejeti, kar ne preseneča, saj gre večinoma za kmečko prebivalstvo, ki take informacije potrebuje. Vsak dan pripravijo tudi novice s tega območja. Tudi te so zelo gledane. Prenašajo tudi poročila komercialne televizije POP TV. Program sestavljajo še programi združenja lokalnih televizij, kulturni pregledi, risani filmi za otroke, šport, turizem, kontaktne oddaje in zabavne ter razvedrilne oddaje. Vsak torek pa predvajajo celovečerni film. Ljudje so nam povedali, da ne spremljajo redno tega programa, kar ob tako veliki, raznoliki in kakovostni ponudbi programov ni čudno. 
Lokalni televizijski program je namenjen predvsem obveščanju, izobraževanju in tudi razvedrilu prebivalcev na obeh straneh Gorjancev, z upoštevanjem njihovih potreb po sodobnem, nepristranskem, sprotnem in ižrrpnem seznanjanju z dogodki in življenjem v teh treh pokrajinah).

Najpogosteje spremljajo oglase, obvestila, novice in Kmetijske razglede.

Najpogosteje gledajo programe Televizije Slovenija, prvi in drugi program, POP TV in A-kanal ter televizijski hrvaški program, prebivalci so zaradi bližine meje na tem območju med seboj dokaj povezani, v skupni državi in pri medsebojnem sodelovanju so navezali stike in poznanstva. Kdaj Kostanjevičani gledajo televizijo, je odvisno od programa, starosti in statusa.

\section{Radio Krka}

Tudi radijske postaje imajo svoje poslušalce, pri katerih moramo prav tako upoštevati družbene kategorije. Med mlajšimi je zagotovo pomembnejši Radio Krka, ki pokriva široko območje že prej omenjenih treh regij. Ima

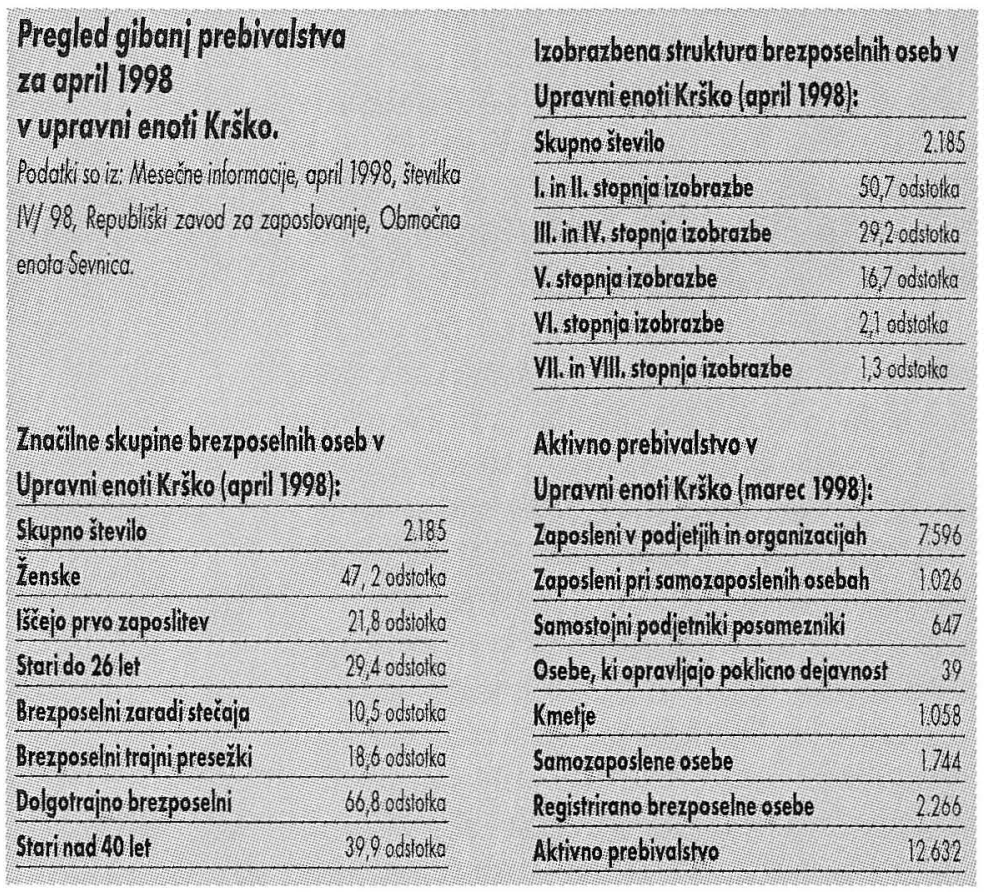

24-urni program, ki je glasbeno obarvan in popestren $z$ aktualnimi dogodki. Program sooblikujejo tudi poslušalci. Sestavljajo ga programski sklopi, kot so pregled domačega in tujega tiska, različni intervjuji, kino spored, osrednja informativna oddaja, planinske informacije, moda, glasbene želje.

Starejši prebivalci poslušajo predvsem Studio Brežice, lokalni radio. Pogosto poslušajo tudi Radio Ognjišče, zlasti verske oddaje, in Radio Slovenija, predvsem prvi program.

Odrasli med dvajsetim in šestdesetim letom, ki imajo višji socialni in družbeni status, pa poslušajo drugi program Radia Slovenija Val 202, predvsem prispevke s strokovno tematiko in zanimivostmi, aktualnimi novicami, popestrenimi z javnim mnenjem in sodelovanjem poslušalcev, ter posebej izbrano glasbo. Večinoma imajo končano srednjo šolo ali višjo izobrazbo. Tretji program Radia Slovenija pa je rezerviran za bolj izobražene ljudi.

Pogosto pa tod odmeva še Studio D - radio Dolenjske in radia Sraka, ki imata širok spekter poslušalcev. Zanimiva sta za starejše in mlajše prebivalce. Za odrasle in starejše so rezervirane jutranje in dopoldanske ure, za mlajše in nekoliko manj mlade pa popoldanske in večerne ure.

\section{Druženje ljudi v službi}

Kostanjevica na Krki je ena izmed krajevnih skupnosti, ki sestavljajo občino Krško. Ker ni podatkov o zaposlitvi samo za to območje, bomo v nadaljevanju prikazali nekaj statističnih podatkov za celotno občino Krško. Ti nam bodo tako lahko služili kot makro vzorec mikrične skupnosti Kostanjevica na Krki.

Kostanjevica ima tri velike delovne obrate, in sicer SOP IKON, Filotec in Lipa.

SOP IKON je podjetje, ki izdeluje klimatske odpraševalne naprave, s približno 70 zaposlenimi. Od tega je približno 50 delavcev in 20 zaposlenih v režiji. Delavci imajo večinoma 
končano srednjo šolo, vendar ne vsi, nekateri, predvsem starejši, le osnovno šolo. Za načrtovanje in vodenje poslov imajo zaposlene $\mathrm{z}$ najmanj srednjo šolo (tehnična šola in visok strokovni kader s končano strojno ali računalniško fakulteto). Pred privatizacijo in lastninjenjem je podjetje večkrat organiziralo sindikalne izlete in piknike, na katerih so se delavci med seboj družili, zdaj pa tega skoraj ni več.

Enako velja tudi za drugi dve podjetji. Lipa je tovarna, ki izdeluje noge za mize. Tudi tu je struktura zaposlenih približno enaka. Delavci so večinoma iz Kostanjevice in bližnje okolice. Njihova povprečna starost je 35 let. Mladega kadra pa je tudi tu zelo malo, saj novega zaposlovanja skoraj ni. Veliko je terenskega dela, zato morajo biti delavci na voljo tudi $\mathrm{v}$ popoldanskem času. Filotec pa je podjetje, ki je nadomestilo Iskro, izdeluje pa elemente za elektroniko. Delavci delajo v dveh izmenah, zaposlenih pa je približno 50 ljudi. Visoko izobraženega kadra je nekaj več kot v drugih dveh podjetjih.

Veliko zaposlenih se vozi na delo v večja središča, kot so Novo mesto (Revoz - tovarna avtomobilov, bolnišnica, Krka - tovarna zdravil, trgovine, obrtniki ...), Krško in Brežice.

\section{Potovanja in dopusti kot vir neformalnega izobraževanja}

$\mathrm{V}$ zimskem in poletnem času se $\mathrm{v}$ nekaterih družinah začne mrzlično pripravljanje obleke, zelenjave, kopalne ali smučarske opreme, natovarjanje avtomobilov in prtljažnikov. To je postalo že običaj, le da mora $v$ zadnjem času marsikatera družina dopust preživeti kar doma.

Zimsko dopustovanje si privošči kar nekaj družin, predvsem mlajših, s šoloobveznimi otroki, in študentje, zlasti iz premožnejših družin. Na smučanje odhajajo v tujino ali na domača smučišča. Bolj kot zimske počitnice pa so vsekakor zanimive poletne. Menimo, da gre za splošno razširjen sterotip, ki je značilen za našo sredino. Preteklo leto so se tisti, ki so si privoščili počitnice, najpogosteje odpravili v sosednjo Hrvaško, in sicer v Nerezine. Zakaj? Skoraj vse tukajšnje delovne organizacije imajo svoje počitniške domove v tem kraju. Pred privatizacijo so imela podjetja več počitniških hišic, ostalo jih je le nekaj. Vendar se je pri prebivalcih ohranil spomin na Nerezine. Če jih vprašamo, kam najpogosteje hodijo na dopust, so to zagotovo Nerezine. Tu gre najpogosteje za družine srednjega socialnega statusa. Ljudje so dopustovali tudi $\mathrm{v}$ Dalmaciji, nekaj pa si jih je privoščilo krajše počitnice tudi na slovenski obali. Tisti z najnižjim socialnim statusom pa so ostali doma in preživeli dopust tako kot vsak drug dan $\mathrm{v}$ letu. Na vprašanje, ali si želijo dopusta, jih je večina odgovorila, da je tudi doma lepo in da se sčasoma navadiš. Menijo, da je treba vnaprej razmisliti o vsakem tolarju, saj za poletjem pride jesen, ki pomeni dodatne stroške in obveznosti, saj je treba poskrbeti za zimo, kurjavo, obleko, šolske knjige ... Drugi lahko na to mirno pozabijo, kajti že zdavnaj so plačali počitnice v Grčiji, Španiji, na Sejšelih.

\section{LITERATURA}

Temeljno izobraževanje odraslih. Neformalno izobraževanje odraslih, Ljubljana 1994.

Ana Krajnc: Metode izobraževanja odraslih, Delavska enotnost, Ljubljana, 1979.

Turistični informator, Kostanjevica na Krki.

Kostanjevica na Krki, brošura.

Enciklopedija Slovenije, Mladinska knjiga, Ljubljana, 1997.

Slovenske občine, Mladinska knjiga, Ljubljana, 1997.

Mesečne informacije, april 1998, št. IV/98, Republiški zavod za zaposlovanje, Območna enota Sevnica. 